\title{
Nomad aesthetic: Cattle modifications among the northern Turkana of north west Kenya
}

\author{
Maurizio Dioli®
}

\begin{abstract}
Among the Turkana of north western Kenya, as well as in many other eastern African pastoral societies, cattle are not only a source of food but also an essential tool for a man to establish his own concepts of aesthetic and to visibly express his own personal identity and social relationships among his people. A Turkana man achieves these objectives by choosing a specific male cow and then modifying its external appearance with branding to permanent alter the coat, with a forceful modification of the growth direction of the horns, and with peculiar cuttings of the ear margins and dewlap. These modern-day practices are identical to the images of cattle present in numerous Neolithic rock art scenes over widespread geographical areas. This present-day Turkana custom may facilitate a correct interpretation of prehistoric rock art and help to understand the systems of thoughts, values and aesthetic perceptions of long-vanished prehistoric pastoral societies.
\end{abstract}

Keywords: Turkana, East African pastoralist, Cattle modifications, Branding, Horn deformations, African rock art

\section{Introduction}

The information presented here was gathered during a decade of work as a Veterinary Officer in northern Turkana County, an area of Kenya west of Lake Turkana, bordering Sudan, Uganda and Ethiopia (Fig. 1), and various travels to north-eastern Uganda (Karamoja, Kidepo).

\section{Study area}

The area is populated by the Turkana, a homogeneous Eastern Nilotic group belonging to the "Karamajong Cluster", comprising several closely related ethnic groups that speak a mutually intelligible language. The component tribes include the Karamajong, Jie, Dodoth, Teso (Uganda), Toposa, Jiye (South Sudan) and Nyangatom (Ethiopia) (Gulliver 1952b, 1966, Lamphear 1976, 1988, McCabe 1995, Lokuruka and Lokuruka 2006). Geographically, the region is made up of open plains with sparse scattered mountain ranges and several seasonal rivers. The area is characterized by high temperatures, frequently exceeding $30^{\circ} \mathrm{C}$, and aridity, with an annual rainfall generally in the range of 200 to $300 \mathrm{~mm}$, which falls in very scattered and highly irregular showers (Turkana County

Correspondence: camel4ever@fastemail.us

Riu Tajo 15A, Alfaz del Pi 03580, Alicante, Spain
Government 2013). Droughts are common, and while areas of higher elevation receive more rainfall, agriculture is limited to a few riverine zones (McCabe 1987, Rutten 1989, Opiyo et al. 2015). Because of such harsh ecological conditions, the Turkana are highly mobile pastoralists, managing a variety of livestock species (small stock, donkeys, cattle and camels) and balancing the challenges of living in an unpredictable ecosystem with a complex social network (Gulliver 1958, Wienpahl 1984, McCabe 1990, 1995, De Vries et al. 2006, Juma 2009, 2016).

\section{Methods}

For the Turkana and all the ethnic groups of the Karamajong Cluster, as well as to various degrees many of their neighbours - the Mursi, Dassanetch, Hamar, Suri and other more distant groups such as the Nuer, Ngok Dinka, Longarim (Herskovits 1926, Nalder 1937, Hazama 2012), cattle are the most prized livestock. Cattle are not only a source of food, supplying meat, milk and blood, but they are also overwhelming important in all aspects of social life (Cummins 1904, Evans-Pritchard 1940, 1953, 1956, Beaton 1950, Clark 1952, Kronenberg 1961, Gulliver 1966, Gourley 1972, Tornay 1981, Fukui 1984, Abbink 2003, Dubosson 2014, Insoll et al. 2015). Among the listed 


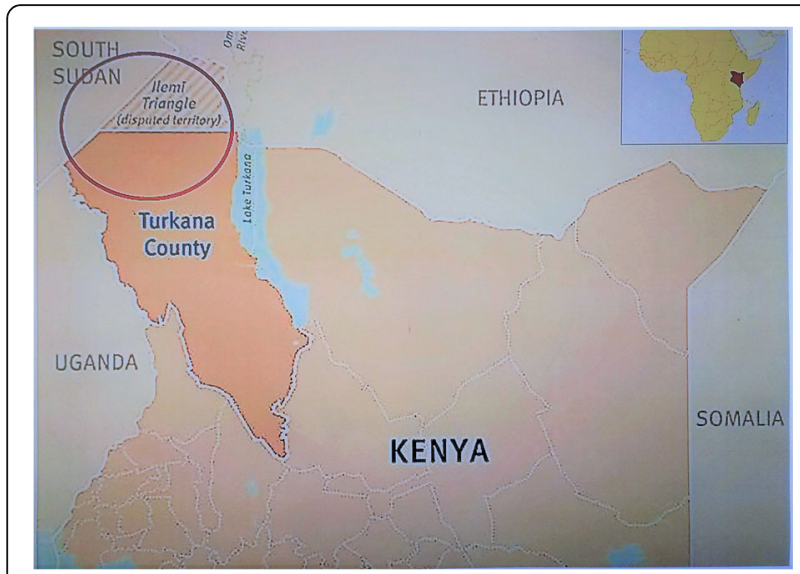

Fig. 1 Turkana map. The circled area indicates the approximate area addressed by the study: (Adapted from World Countries

Layer (https://www.arcgis.com/home/index.html)

ethnic groups, a man is known by his contemporaries and friends not only by his given birth name but also by his "ox-name" - the name of his "favourite-ox", which denotes specific and distinctive characteristics of the chosen ox, including colour of the coat, presence and patterns of spots, shape of horns, fatness or behaviour (Evans-Pritchard 1934, 1940, 1956, Gulliver 1951, Almagor 1972, Tornay 1981, Brown 1990, Dubosson 2014). Turkana adherence to such social custom is highly developed, and the oxname of the favourite-ox - emong lodwarat (Ohta 1987) or emong lo edwaritae (Barret 1998) - is widely used to identify a man in addition to his birth name (Barton 1921, Gulliver 1952a, 1966, Gourley 1972). The ox-name is regularly used by the Turkana in social interactions, including dances where Turkana singers extol the qualities of their favourite-ox (Gulliver 1951, 1952a, Robbins and Robbins 1971, Ohta 1987, Barrett 1998, Hazama 2012). The favourite-ox of the Turkana is generally a castrated male with a very particular appearance, artificially developed through a variety of complex coat and body modifications and horn deformation (Gulliver 1951, 1952a, Evans-Pritchard 1953, 1956, Almagor 1972, Turton 1980, Brown 1990, Dubosson 2014, Insoll et al. 2015). While a Turkana woman may own livestock, the feature of the ox-name is an entirely male feature. As reported by Gulliver (Gulliver 1966: 59), male children from the age of about four years receive an ox-name from their father or uncles.
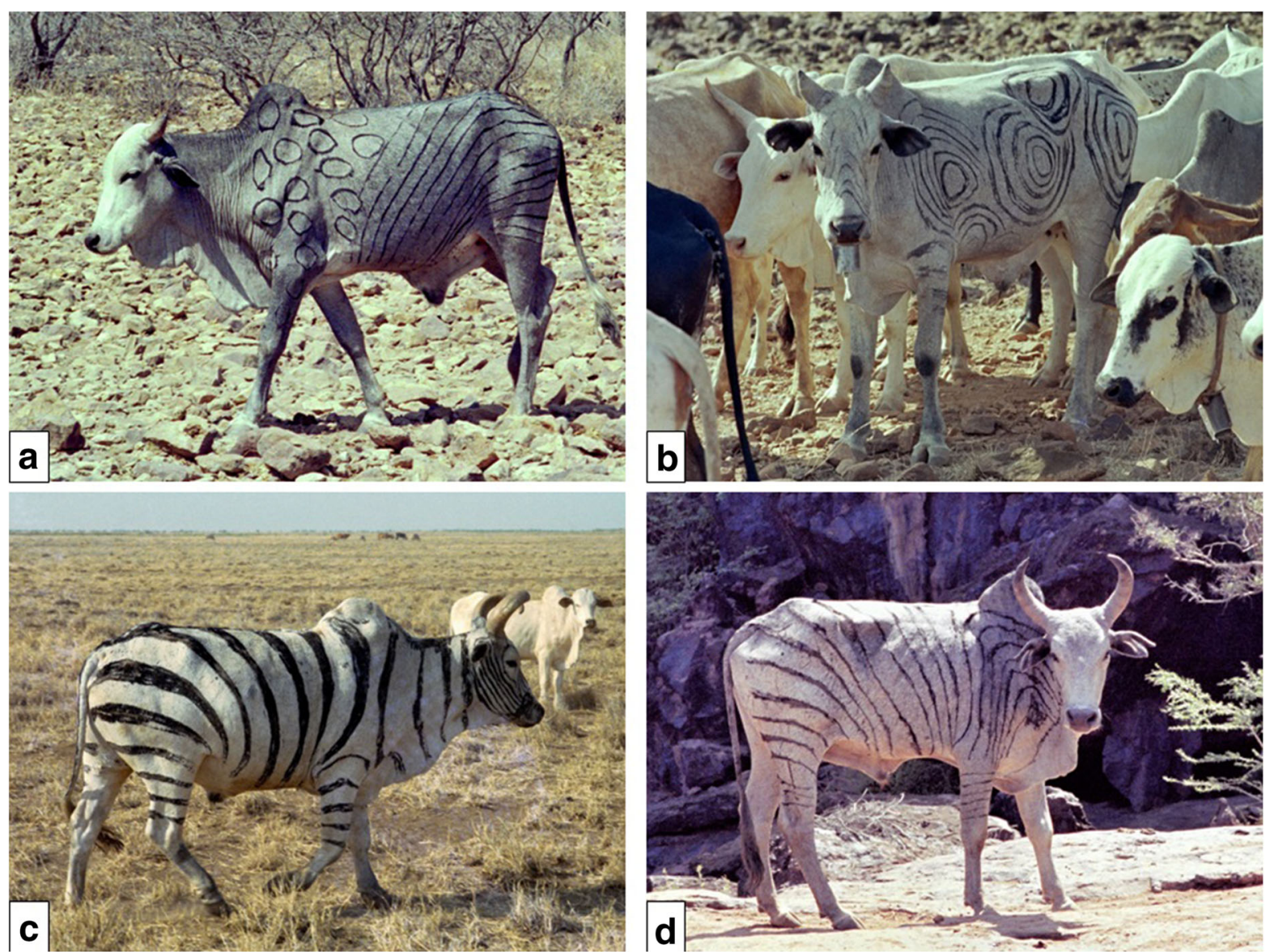

Fig. 2 Favourite-oxen of various localities in North West Turkana: a, b, d Songot Mountain, c Lotikipi Plain 


\section{Results and Discussions}

The cattle chosen by a Turkana to become "favouriteoxen" are invariably castrated at one to two years of age. Castration can be surgical, involving physical removal of testes through cuts in the scrotum, or non-surgical using a wooden hammer (ekidonget) and repeatedly beating the spermatic cord areas over the base of scrotum on an underlining wooden surface. The trauma disrupts blood supply to the testes, leading to subsequent tissue deterioration and atrophy. Castration is done to render the animal more docile and enhance growth, resulting in a taller and fatter animal that is better able to survive periodic fodder shortages. The preferred coat colour for a favourite-ox is uniform and pale, and can be white, gray, yellow or pale roan. However, in order to avoid competition, close agnates frequently choose cattle of different colours, even including brindled or pied coats. The preference for paler coat colours is because a coat "beautification" process is adopted: firing or branding in a specific pattern that causes the hairs of the fired area to grow back much darker than the surrounding undamaged skin. A paler background ensures a more visible result.

\section{Pattern branding}

The practice of "pattern branding" among the Turkana consists of branding a set of regular, geometric patterns over the coat of the favourite-ox. The custom has been documented in other ethnic groups neighboring the Turkana such as the Hamar (Dubosson 2014), Mursi (Insoll et al. 2015), Toposa, Karimojong, Jje, Dodoth (Gulliver 1952a, 1952b), Dassanetch (Almagor 1972), and Longarim (Kronenberg 1961). Pattern branding is done by using variously shaped iron implements that are not very dissimilar to the tools used in branding for traditional ethno-veterinary purposes (Mathan-Kumar et al. 2012) or those used to indicate ownership (Gramly 1975, Ohta 1984, 1987, Russell and Kiura 2011). Branding for ownership is a widespread husbandry practice adopted worldwide both by traditional pastoralists and modern commercial ranchers (Landais 2001) and even reportedly by ancient Egyptians as recorded in the painting of the Nebamun tomb from 1400 BC (Wilkinson 1979). Pattern branding, however, differs from ownership branding because the objective is not to obtain a permanent scar brand but a lesser degree of skin damage that allows coat hairs in the
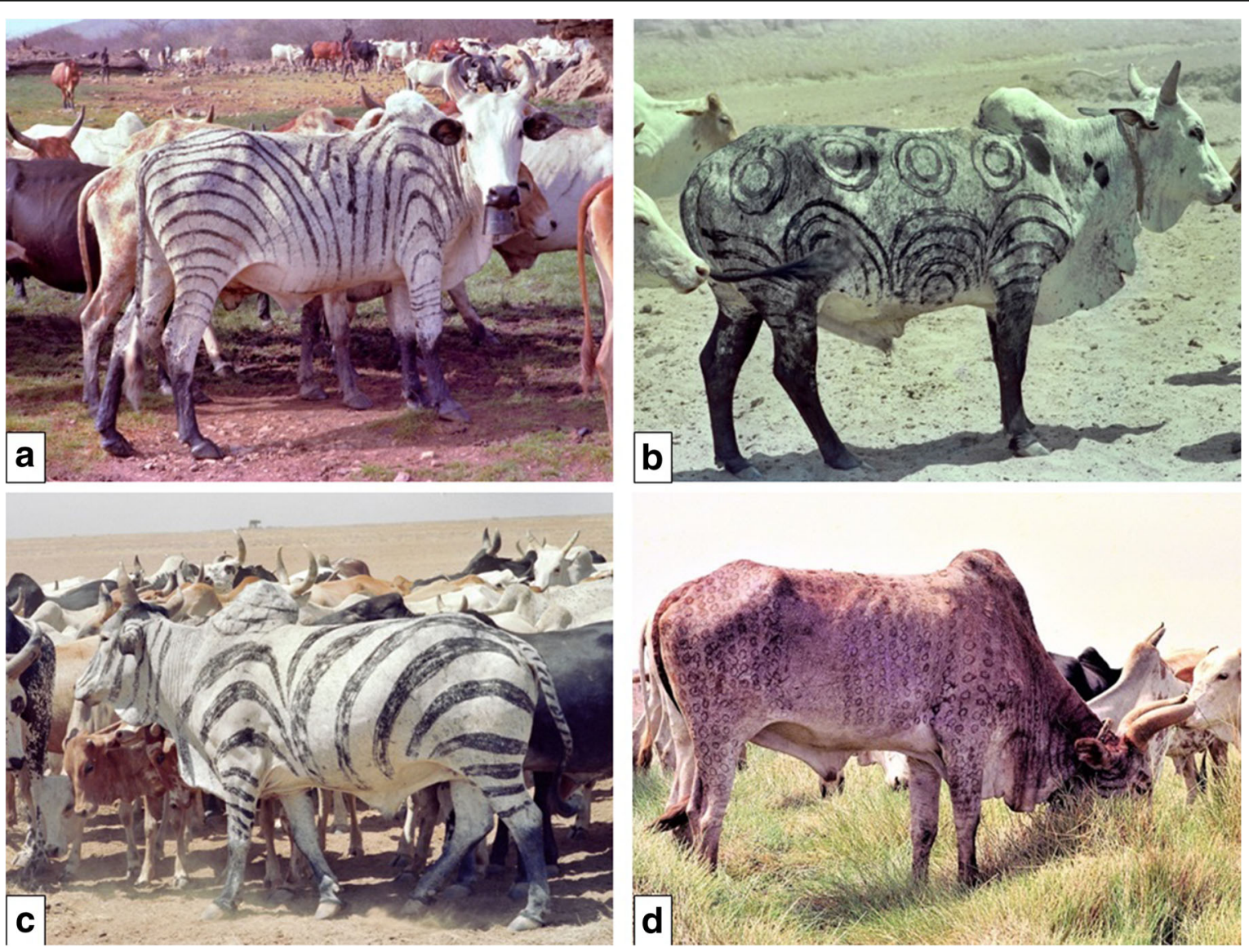

Fig. 3 Favourite oxen of various localities in North West Turkana: a, d Mogila Mountain, b Lokamarynyang (llemi Triangle), c Lotikipi Plain 
branded area to grow back. This is achieved by using a cooler branding iron and applying it to the coat for a shorter time so as not to kill the hair growth cells of the branded area. Hair grows back, but because of the increased concentration of the local skin pigment, it grows with much more of the original coat pigment. Gray hair thus grows back black, yellow hair dark brown and roan hair dark red. It must be noted that pattern branding is also different from freeze-branding because that destroys the pigmentproducing cells in the hair follicles, resulting in the regrowth of white hair over the branded area (Hall et al. 2004). The end result of pattern branding can render the favourite-ox esthetically startling, as indicated by a variety of modified Turkana favouriteoxen in Figs. 2 and 3. Occasionally, pattern branding is simply limited to branding in a pinpoint pattern over the head of the ox to produce a pattern of numerous black spots (Fig. 7a) and on both sides of the tail (Fig. 7b).

\section{History of pattern branding}

Ox coat modification through pattern branding is a practice that has apparently been carried out for thousands of years and by numerous ethnic groups dispersed over a large geographical area. This is demonstrated by prehistoric rock art of cattle with unnatural coats from various regions in Africa. The Neolithic rock art at Sullum Ba'atti, Eritrea, depicts several cattle with coats of various geometrical patterns (Franchini 1951, 1952, Calegari 1999). Among the most intriguing examples are figures of cattle with vertical stripes on their coat (Fig. 4b) that are extremely similar to the favourite-ox of a modern-day Turkana (Fig. 4a). Such striped coat patterns for cattle are depicted in the rock art of Immidir, Algeria (Gauthier and Gauthier 2006), and Tassili-nAjjer, Algeria, which date to between 4000 and 2000 BC. Among cattle with normal coat colours, there are those with striped coats, described as "robe fantaisiste" or "fantasy coats" (Dupuy and Denis 2011). Another striking example of pattern branding in antiquity is the
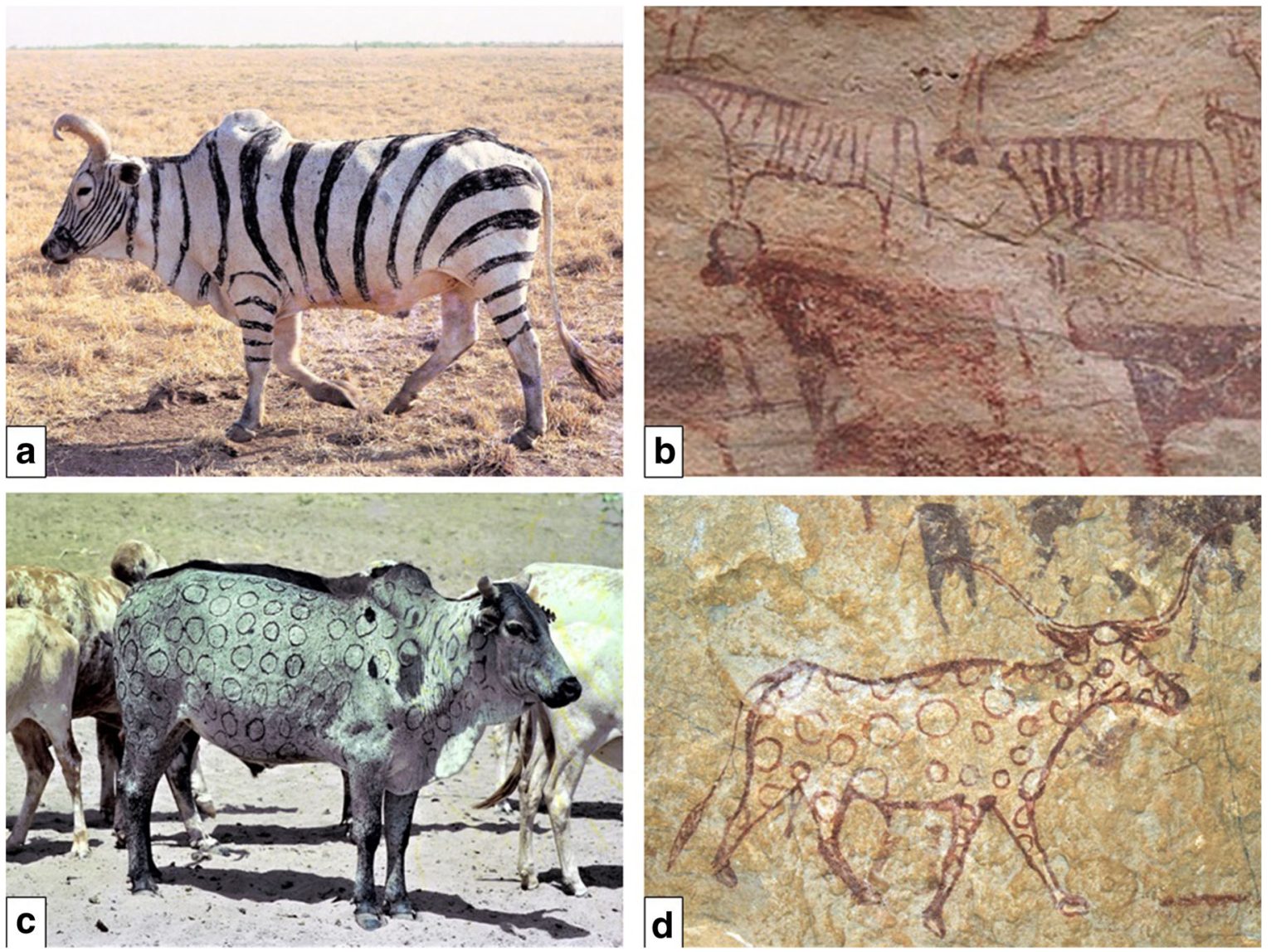

Fig. 4 Modern day favourite-oxen on the left and their mirror-like representation in prehistoric rockart of various African areas on the right. a "Striped ox", Lotikipi Plain. b Ox with a similar coat modification from rock art found at Sullum Ba'atti, Eritrea (courtesy G. Calegari). c "Circled ox", Lotikipi Plain. d Ox with a similar coat modification from rock art found in Immidir, Algeria, approx 4000 BC (courtesy Y. Gauthier) 
drawing of an ox with a circular pattern on its coat from 4000 BC rock art in Immidir, Algeria, (Fig. 4d) (Gauthier et al. 1996), which mirrors modern day branding of a Turkana favourite-ox (Fig. 4c).

While it has been noted that some of the Turkana cattle pattern brandings resemble the engravings found on and around items at the Namoratunga archaeological burial site (Lynch and Robbins 1977), investigations have discounted any possible influence on recent Turkana occupation of such a geographical area and of the exceedingly "leading" approach used by Lynch and Robbins (1977) rather than one of actually comparing the engravings as they appear on Turkana livestock (Soper 1982, Russell and Kiura 2011).

\section{Horn deformation}

Another very visible body modification made to a Turkana's favourite-ox is deformation of the animal's horns by redirecting their growth. The practice of horn deformation is widely used among the Turkana, as evidenced by the richness of the Turkana's vocabulary to describe the various horn shapes that can only be artificially achieved: 18 different terms for corresponding different artificial horns shapes (Ohta 1987). Horn shapes can be modified by carefully carving the horn in specific areas to stimulate its growth in a particular direction. However, to achieve the most radical horn shapes, the technique used by Turkana requires fracturing the horns so as to reposition them in a new direction. The procedure, carried on juvenile animals with horns that have already grown to a length of 10 to $15 \mathrm{~cm}$, is done by repeatedly pounding around the base of the horn with a round smooth stone to weaken the bone core base and subsequently pulling and wresting the horn manually until the horn bone core at the base is fractured. Once this has been achieved, the horns are turned, twisted and bent in the direction in which they are desired to grow: being rotated and bent forward for a forward curved growth (Fig. 6a). In some cases, the fractured horns require to be kept in the chosen position artificially. If a vertical parallel growth is desired,

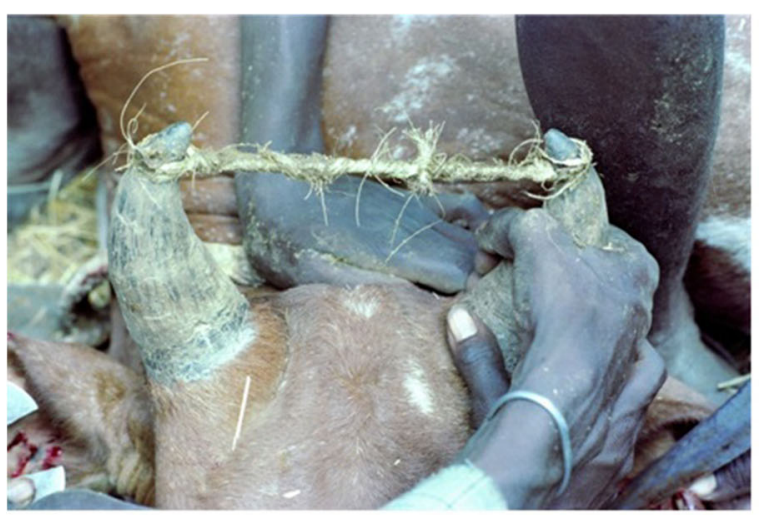

a
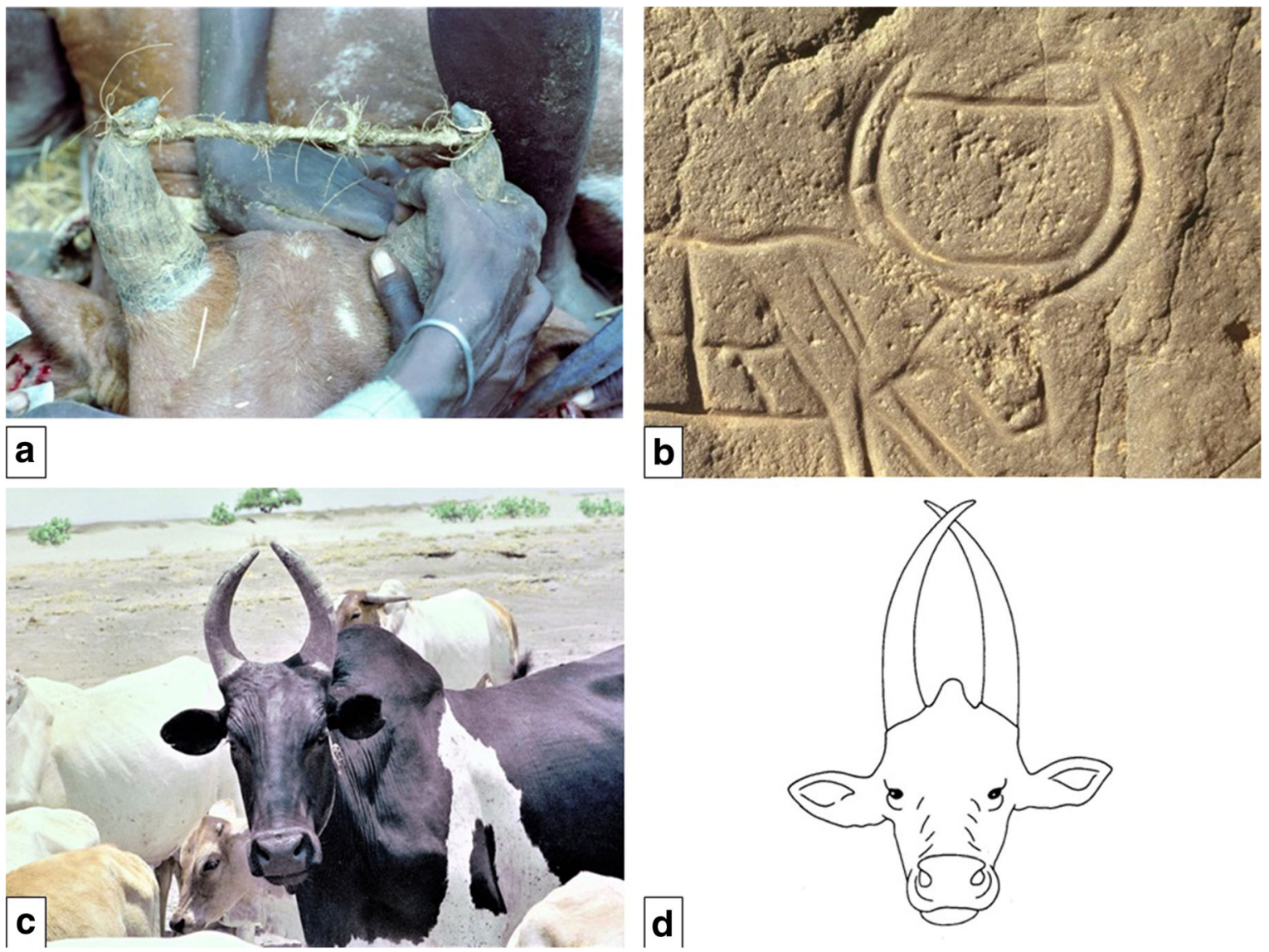

Fig. 5 Horn deformation: a live ox just after the procedure of "vertical horn deformation": the horn bone cores have been broken, the horn sheath smove upright and close to each other and are fixed in such a position with a rope between the horn tips. Lotikipi Plain. $\mathbf{b}$ A depiction of a similar technique in the rock art of Wadi Mathendous area, Libya, approx 7000 to 6000 BC (David Coulson, Trust for African Rock Art). c An adult ox with horns growing according to the vertical horn deformation. $\mathbf{d}$ Interpretation of a cattle skull remains found at a cattle bucrania in Kerma, Sudan (Chaix and Hansen 2003, Chaix et al. 2012) 
the horns' notched tips are tied to each other diagonally with a rope made usually with fibres of Sansevieria ehrenbergii (Fig. 5a). If asymmetric horn growth, "one up one down", is desired (Fig. 6c), the fracturing procedure is carried out only on one horn, and after lowering the horn toward the front, a thread is attached to the notched horn tip of the modified horn to a purposely cut hide loop over the bridge of the nose. Horn deformation has been recorded for cattle of many other Eastern African ethnic groups: the Karimojong, Jie (Gulliver 1952b), Dodoth (Thomas 1966), Hamar (Dubosson 2014,), Bodi, Dassanech (Almagor 1972), Hamar (Chaix et al. 2012), Mursi (Insoll et al. 2015), Nyanyatom, Suri (Abbink 2003), Murle (Lewis 1972), Pokot (Brown 1990), Dinka, Nuer (Evans-Pritchard 1940, Seligman 1932) and Longarim (Kronenberg 1961).

\section{History of horn deformation}

There is evidence that horn deformation has been practiced by many ancient African ethnic groups. Many cattle skulls have been excavated from funerary bucranias (a set of cattle skulls place in or around a burial). Numerous cattle skulls placed in a croissant shape on the southern border of a tomb, in the eastern cemetery of the ancient (2500 to 1500 BC) city of Kerma (Honegger et al. 2009, Chaix et al. 2012), northern Sudan, revealed unnatural horn shapes, vertical parallel horns or one horn pointing downwards and the other upwards, suggesting that such shapes could only have been achieved by artificial means (Chaix 1996, 2001, 2004a, 2004b, 2006, Chaix and Hansen 2003). Such archeological findings were also discovered in burial areas closer to Egypt. Those in Faras (Hall 1962) suggested that such customs were also carried out by ancient Egyptians. This is confirmed by the representation of cattle with obvious artificial horn deformation on the East Wall reliefs of the tomb of Ptahhotep (Fig. 6d) (Quibell 1896), on the south wall of the offering hall of Manofer in Saqqara (Egypt) from approximately 2500 BC (Altenmüller 2006), in the decorated chapels of the Meroitic Pyramid at Meroe (Chapman and Dunham 1952) and in many other Egyptian bas-reliefs (Vandier 1969). The

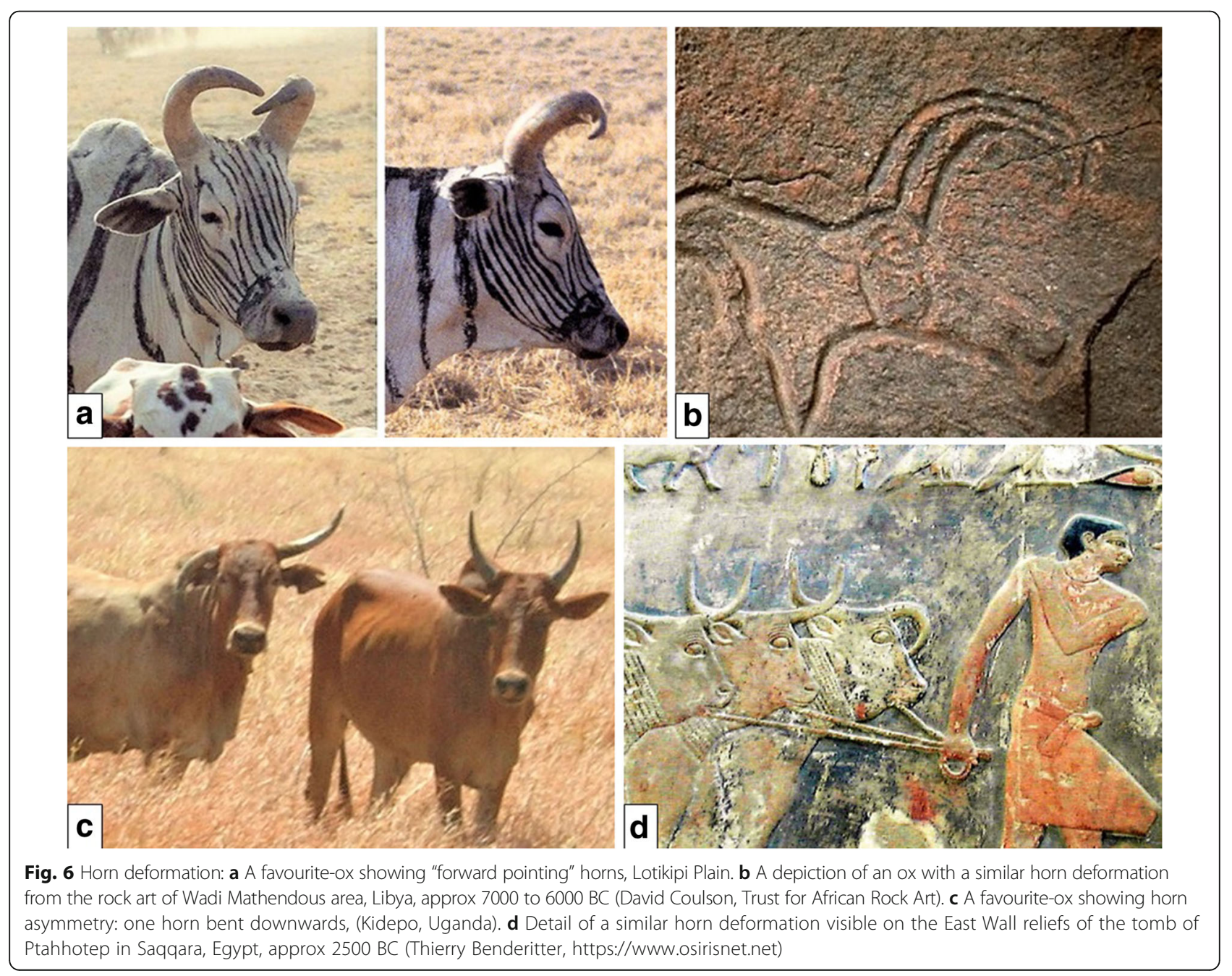


practice of horn deformation by ancient Egyptians may suggest that they were responsible for introducing such a custom southwards to other African ethnic groups (Seligman 1932, Seligman and Seligman 1950). While such a hypothesis is attractive, it is probably not the case because horn deformation is not continuously and commonly represented in Egyptian tombs (Schwabe 1984), and furthermore, artificial horn shapes have appeared in the rock art of various Neolithic cultures of several Saharan regions, all substantially pre-dating Egyptian civilization (Huard 1959, Huard and Massip 1963, Chaix 2004a, b, Searight 2004). For example, rock art of the Wadi Mathendous, in Libya, of approximately 7000 to $6000 \mathrm{BC}$, shows a similar technique used to maintain parallel vertical growth of the horns, the fractured horns being kept in the chosen position by a rope tied between the notched tips (Fig. 5b),

\section{Modification of other body areas}

In addition to the coat and the horns being modified, there are other body parts of a favourite-ox that may be the subject of modifications. Among the Turkana, as with many other pastoralist groups, the ears of the cattle are often chosen for making various types of ownership marks (Ohta 1987, Barrett 1998). However, for decoration purposes, a specific ear cut is implemented: a series of straight cuts, approximately $2 \mathrm{~cm}$ in length, are made across the upper and lower margins of both ears using a wrist knife (abarait) that every male Turkana wears (Fig. 7c). The Mursi of Ethiopia perform a similar pattern of ear cutting (Eczet 2015). The subsequent inevitable infection of the wounds in the cartilage along the ear margins ensures development of a well-spaced saw-tooth pattern (Fig. 7d). Another area occasionally selected for modification is the dewlap, where single (Fig. 8a) or multiple skin cuts (Fig. 8c) are made in such a way as to produce flaps of pendulous hanging skin of various lengths. Such a custom is also apparent among the Hamar of Ethiopia (Dubosson 2006, 2014).

\section{History of modification of other body areas}

Hard evidence that modifications of other body parts of cattle were done in prehistoric times by ancient African ethnic groups is difficult to obtain because soft tissue
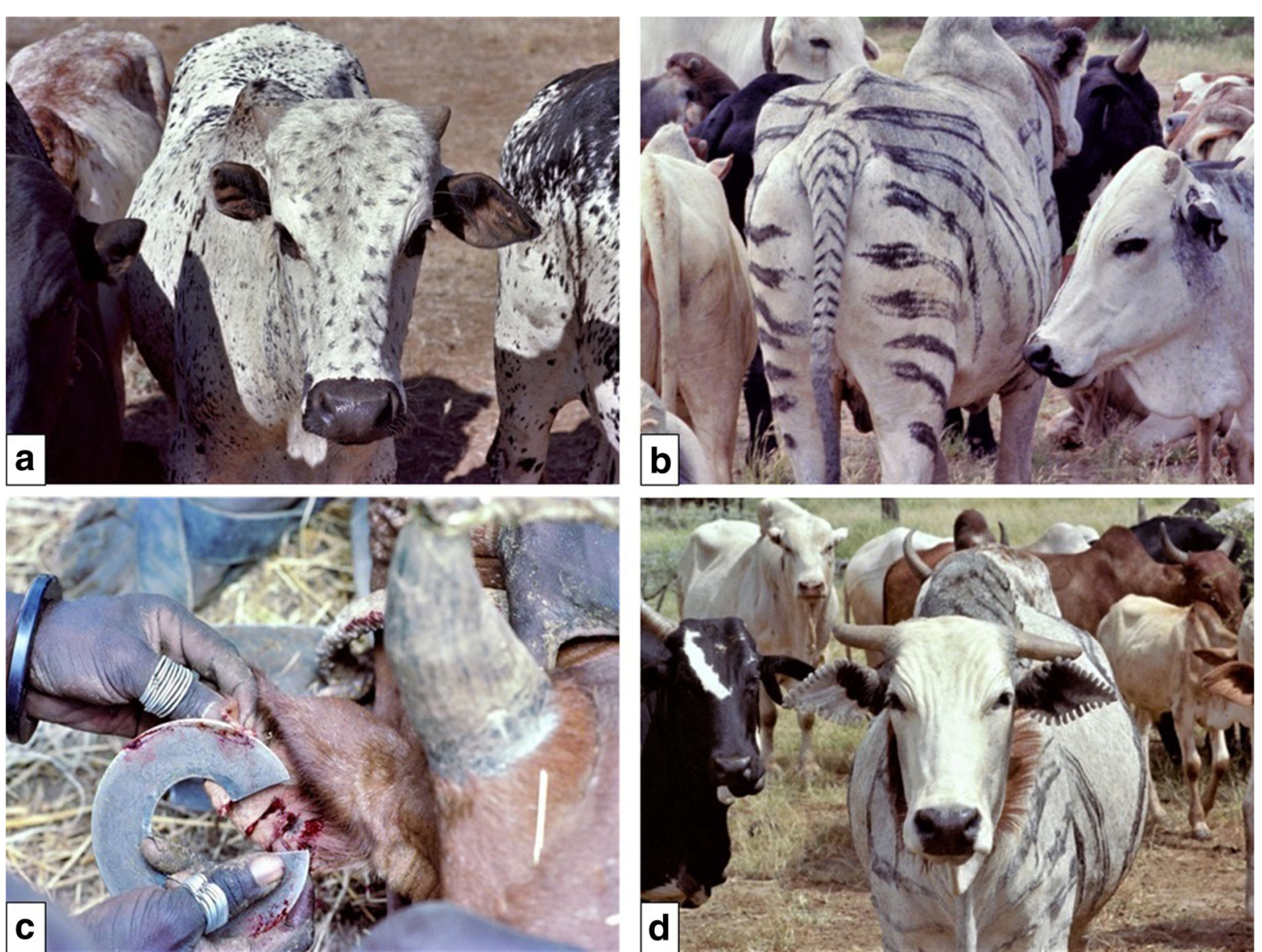

Fig. 7 a Detail of the head of a favourite-ox with numerous blackish spots obtained by "spot branding", Oropoi. b Detail of the tail of a favourite-ox with numerous black lines, Oropoi. c Ear of favourite-ox being decorated, Lotikipi Plain. $\mathbf{d}$ Head of a favourite-ox showing ear pattern decoration, Oropoi 

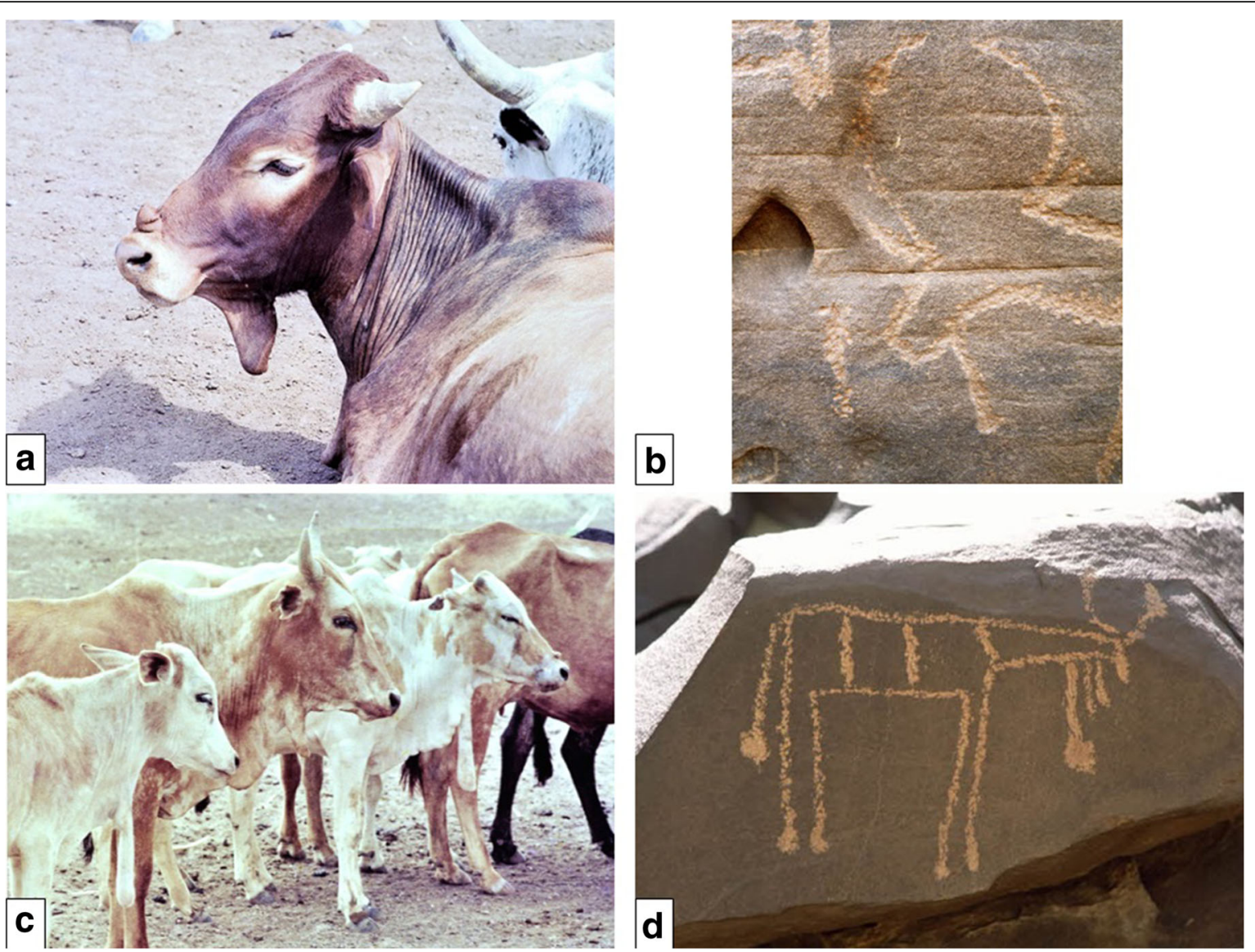

Fig. 8 a Head of a favourite-ox showing a flap of hanging skin in the chin area. b Detail of rock art depicting an ox with a similar hanging skin modification, Air Mountains, Niger, approx 3000 BC. (David Coulson, Trust for African Rock Art). c Three cattle showing dewlaps with hanging skin flaps of various length, Lokwnamoru. $\mathbf{d}$ Rock engraving showing a cow with similar hanging skin flaps from dewlap, Air Mountains, Niger, approx 3000 BC (David Coulson, Trust for African Rock Art)

remains rarely endure at archaeological sites. However, Neolithic rock art in north-western African countries, such as Morocco (Searight 2004, 2013) and Niger (Fig. 8b, d), shows cattle with dewlap modifications comparable with that practiced by modern day Turkana on their favourite-oxen. Ear markings have not been recorded in ancient African rock art scenes, but this may simply be because drawing it represented technical challenges to Neolithic artists.

\section{Conclusions}

This article is embracing the interpretation of ethnoarcheology put forward by David and Kramer: "ethnoarcheology is neither a theory or method but a research strategy" that includes "a range of approaches to understanding the relationship of material culture to culture as a whole, both in the living context and as it enters the archaeological record, and to exploiting such understandings in order to inform archaeological concepts and to improve interpretation" (David and Kramer 2001: 2). This concept is more clearly summarized by the definition of the archeologist Lewis Binford: ethnoarchaeology is a "Rosetta stone: a way of translating the static material found on an archaeological site into the vibrant life of a group of people who in fact left them there" (Binford 1983: 24). Turkana cattle modifications the creation of a favourite-ox - are powerful and very visible, representing a tool with which individual Turkana are able to establish and affirm a vast array of cultural and social relationships at individual and family levels and among the various clans. As stated by Barrett (Barrett 1998: 2), who studied the Turkana extensively, "man creates the identity of the animal and the animal gives identity to man". Cattle represent the pivotal element of life for the Turkana, and it is logical that the favourite-ox is a chosen tool to express a Turkana's personal concepts of beauty and his idealized "public persona", in addition to his relationship to the world. The Turkana cattle-centered lifestyle is a classic example of people developing their visual aesthetic feelings through an easily available common object, which Gombrich terms "the marvel of everyday vision" 
(Gombrich 1977: 275 quoted by Coote 1992). It is undeniable that the Turkana favourite-ox coat patterns, horn deformations and body modifications are similar to cattle images present in numerous Neolithic rock art scenes from a broad range of geographical areas. Such a fact might help to better understand and interpret livestock images found in prehistoric rock art from a variety of African and European sites. More importantly, it can be argued that the Turkana's favourite-ox is a present-day tool that allows anthropologists to understand better the systems of thought, values and aesthetic perceptions of long-vanished prehistoric pastoral societies that produced similar rock art images.

\section{Acknowledgements}

My thanks to the countless Turkana nomads for their help and hospitality and to Prof. Itaru Ohta, Prof. Terrence McCabe, Dr. Carol Kerven, Dr. Jorome Dubosson, Dr. Marcel Rutten, Dr. Yves Gauthier and Dr. Giulio Calegari for their productive comments on the manuscript. Sincere thanks also to Prof. Jonathan Robinson for editing the manuscript's English.

\section{Ethics approval and consent to participate}

In every case, prior informed consent was obtained verbally before the interview was conducted, according to the ethical guidelines adopted by the American Anthropological Association (1998) and by the International Society of Ethnobiology (2006).

\section{Competing interests}

The author declares no competing interests.

\section{Publisher's Note}

Springer Nature remains neutral with regard to jurisdictional claims in published maps and institutional affiliations.

Received: 31 October 2017 Accepted: 12 December 2017

Published online: 07 February 2018

\section{References}

Abbink, J. 2003. Love and death of cattle: The paradox on Suri attitudes toward livestock. Ethnos 68: 341-364.

Almagor, U. 1972. Name-oxen and ox-names among the Dassanetch of southwest Ethiopia. Paideuma 18: 79-96.

Altenmüller H. 2006. Presenting the ndt-hr-offerings to the tomb owner. In: Bárta, M. (Ed): The Old Kingdom art and archaeology, Proceedings of the Conference Held in Prague, May 31-June 4, 2004. Prague, 25-35.

Barrett, J. A. 1998. Turkana iconograph: Desert nomads and their symbols. In Symbols, rituals, myths. Lodwar: Kenya.

Barton, J. 1921. Notes on the Turkana Tribe of British East Africa. Part II. Journal of the Royal African Society 20(79): 204-211.

Beaton, A. C. 1950. Record of the Toposa tribe. Sudan Notes and Records 31 (1): $129-132$

Binford, L. R. 1983. In pursuit of the past: Decoding the archaeological record. New York: Academic Press

Brown, J. 1990. Horn-shaping ground-stone axe-hammers. Azania 25: 57-67.

Calegari, G. 1999. L'arte rupestre dell'Eritrea: repertorio ragionato ed esegesi iconografica, Memorie della Società Italiana di Scienze Naturali e del Museo Civico di Storia Naturale di Milano, Volume XXIX (1), Milano.

Chaix, L. 1996. Les boeufs à cornes parallèles: archéologie et ethnographie. Sahara 8: 95-97.

Chaix, L. 2001. Animals as symbols, the bucrania of the grave KN24 (Kerma, Northern Sudan). In Animals and man in the past. Essays in honour of Dr. A.T. Clason Emeritus Professor of Archeozooology, ed. H. Bruitenhuis and W. Prummel, 364-370. Groningen: ARC-Publicatie 41.

Chaix, L. 2004a. Les boeufs africains à cornes déformées: quelques élément de réflexion. Anthropozoologica 39 (1): 335-342.

Chaix, L. 2004b. Déformations anciennes et actuelles du cornage bovin en Afrique du Nord-Est. In Élevage d'hier, élevage d'aujourd'hui. Mélanges d'ethnozootechnie offerts à Bernard Denis, Rennes: Presses universitaires de Rennes, ed. C. Guintard and C. Mazzoli-Guintard, 21-32.

Chaix, L. 2006. Boeuf a cornes deformees et beliers a spheroide: de l'art rupestre a l'archeozoologie. In: Gauthier Y., Le Quellec, J.-L., Simonis, R., (ed.) Hic sunt Leones, Melanges sahariens en I'honneur d'Alfred Muzzolini, Cahiers de I'Association des Amis de l'Art ripestre Saharien, 10: 49-54.

Chaix, L., J. Dubosson, and M. Honegger. 2012. Bucrania from the Eastern Cemetery at Kerma (Sudan) and the practice of cattle horn deformation. Studies in African Archaeology 10: 185-208.

Chaix, L., and J. W. Hansen. 2003. Cattle with "forward-pointing horns": Archaeozoological and cultural aspects. In Cultural markers in the later prehistory of Northeastern Africa and recent research, ed. L. Krzyzaniak, K. Kroeper, and M. Kobusiewicz, vol. 8, 269-281. Poznan: Studies in African Archaeology.

Chapman, S. E., and D. Dunham. 1952. Decorated chapels of the meroitic pyramids at Meroë and Barkal, Royal cemeteries of Kush, 50. Boston: Museum of Fine Arts.

Clark, D. 1952. Memorial service for an ox in Karamoja. Uganda Journal 16: 215-

Coote, J. 1992. 'Marvels of everyday vision': The anthropology of aesthetics and the cattle-keeping Nilotes. In Anthropology, art, and aesthetics, ed. J. Coote and A. Shelton, 245-273. Oxford: Clarendon,

Cummins, S. L. 1904. Sub-tribes of the Bahr-El-Ghazal Dinkas. The Journal of the Anthropological Institute of Great Britain and Ireland 34: 149-166.

David, N., and C. Kramer. 2001. Ethnoarchaeology in action. Cambridge, MA: Cambridge University Press

De Vries, D. H., P. W. Leslie, and J. T. McCabe. 2006. Livestock acquisition dynamics in nomadic pastoralist herd demography: A case study among Ngisonyoka herders of South Turkana, Kenya. Human Ecology 34 (1): 1-25

Dubosson, J. 2006. Le statut des bovins et de leur cornage dans les sociétés pastoralesd'Afrique de l'est : approche ethnoarchéologique. Neuchâtel, Institut de préhistoire et des sciences de l'antiquité. Université de Neuchâtel

Dubosson, J. 2014. Human 'self' and animal 'other'. The favourite animal among the Hamar. In Ethiopian images of self and other, ed. F. Girke, 83-104.

Dupuy, C., and B. Denis. 2011. Les robes des taurins dans les peintures de la Tassilin-Ajjer (Algérie): polymorphisme ou fantaisies? Les Cahiers de l'AARS, 29-46. Saint-Lizier: Association des amis de l'art rupestre saharien.

Eczet, J. B. 2015. Des hommes et des vaches: L'attachement entre les personnes et leursbovins en pays Mursi (Éthiopie). Anthropologie et Sociétés 391 (2): $121-144$.

Evans-Pritchard, E. E. 1934. Imagery in Nǵok Dinka Cattle-Names. Bulletin of the School of Oriental and African Studies 7 (3): 623-628.

Evans-Pritchard, E. E. 1940. The Nuer: A description of the modes of livelihood and political institutions of a Nilotic people. Oxford: Clarendon.

Evans-Pritchard, E. E. 1953. The sacrificial role of cattle among the Nuer. Africa 23: 181-198.

Evans-Pritchard, E. E. 1956. Nuer religion. Oxford: Clarendon.

Franchini, V. 1951. Pitture rupestri a Sullum Baatti. Rassegna di Studi Etiopici 10: $122-123$

Franchini, V. 1952. Pitture rupestri a Ba'attì Sullùm nel Deghien. Rassegna di Studi Etiopici 11: 47-48.

Fukui, K. 1984. A preliminary report on Pastoralism among the Narim. SudanSahel Studies vol. 1, Research Institute for Languages and Cultures of Asia and Africa, Tokyo University, 75-94

Gauthier, Y., and C. Gauthier. 2006. Monuments en trou de serrure et art rupestre: sur la distribution du groupe d'l'heren-Tahilahi/Wan-n-Amil et ses relations avec les autres groupes culturels. In Hic sunt leones. Mélanges sahariens en I'honneur d'Alfred Muzzolini (Cahiersde I'AARS 10), ed. Y. Gauthier, J.L. Le Quellec, and R. Simonis, 79-110.

Gauthier, Y., C. Gauthier, A. Morel, and T. Tillet. 1996. L'Art du Sahara. Paris: Le Seuil.

Gombrich, E. H. 1977. Art and illusion: A study in the psychology of pictorial representation. 5th ed, 386. London: Phaidon.

Gourlay, K. A. 1972. The ox and identification. Man (N.S.) 7 (2): 244-254.

Gramly, R. M. 1975. Meat-feasting sites and cattle brands: Patterns of rockshelter utilization in East Africa. Azania: Archaeological Research in Africa 10(1): 107-121.

Gulliver, P. H. 1951. A preliminary survey of the Turkana. A report compiled for the Government of Kenya. Communication from the School of African Studies, N.26(n.s.). University of Cape Town, South Africa.

Gulliver, P. H. 1952a. Bell-oxen and ox-names among the Jie. Uganda Journal 16: $72-75$. 
Gulliver, P. H. 1952b. The Karamojong Cluster. Africa 22: 1-22.

Gulliver, P. H. 1958. The Turkana age organization. American Anthropologist, New Series 60 (5): 900-922.

Gulliver, P. H. 1966. The family herds: A study of two pastoral tribes in East Africa, the Jie and Turkana. 2nd ed. London: Routledge and Keagan Paul LtD.

Hall, H. 1962. A note on the cattle skulls excavated at Faras. Kush 10: 58-61.

Hall, J. B., Greiner, S. P., Gregg, C. 2004. 'Cattle identification: freeze branding' Publication Number 400-301. Available at: http://pubs.ext.vt.edu/content/dam/ pubs_ext_vt_edu/400/400-301/400-301_pdf.pdf. Accessed 5 Apr 2017.

Hazama, I. 2012. Daily life as poetry: The meaning of the pastoral songs of the Karimojong in Northeastern Uganda. Nilo-Ethiopian Studies 17: 27-49.

Herskovits, M. J. 1926. The cattle complex in East Africa. American Anthropologist. 28: 230-272, 361-388, 494-528, 633-664.

Honegger, M., C. Bonnet, and L. Chaix. 2009. Kerma (Soudan): origine et developpment du premier royaume d'Afrique noire. Archeologie Suisse 32 (1): 1-13.

Huard, P. 1959. Les cornes déformées sur les gravures rupestres du Sahara oriental. Recherches Sahariennes 1: 109-131.

Huard, P., Massip J.-M. 1963. Gravures rupestres du Tibesti méridional et du Borkou. In: Bulletin de la Société préhistorique de France, tome 60, n7-8, Travaux en retard, 468-481.

Insoll, T., T. Clack, and O. Rege. 2015. Mursi ox modification in the lower Omo Valley and the interpretation of cattle rock art in Ethiopia. Antiquity 89: 91-105.

Juma, R. O. 2009. Turkana livelihood strategies and adaptation to drought in Kenya. PhD dissertation. Wellington: Victoria University of Wellington. Available at: http://researcharchive.vuw.ac.nz/xmlui/bitstream/handle/10063/ 1063/thesis.pdf?sequence=1. Accessed 25 Mar 2017.

Juma, R. O. 2016. Live hood strategies in North-Western Kenya: A study of Turkana people's customary response to famine. International Journal of Science and Research. Available at: https://www.ijsr.net/archive/v5i11/ ART20162920.pdf. Accessed 25 Mar 2017.

Kronenberg, A. 1961. The Longarim favourite beast. Kush 9: 258-277.

Lamphear, J. 1976. Aspects of Turkana leadership during the era of primary resistance. The Journal of African History 17: 225-243.

Lamphear, J. 1988. The people of the Grey Bull: The origin and expansion of the Turkana. The Journal of African History 29 (1): 27-39.

Landais, E. 2001. The marking of livestock in traditional pastoral societies. Revue scientifique et technique (International Office of Epizootics) 20: 463-479.

Lewis, B. A. 1972. The Murle. Red chiefs and black commoners, 166. Oxford: Clarendon.

Lokuruka, M. N. I., and P. A. Lokuruka. 2006. Ramification of the 1918 Turkana Patrol: Narratives by Ngturkana. Ethnohistory 53 (1): 121-141.

Lynch, M., and L. H. Robbins. 1977. Animal brands and the interpretation of rock art in East Africa. Current Anthropology 18 (3): 538-539.

Mathan-Kumar, S., Johnson, E. H., Tageldin, M. H. 2012. Wasm - an ethnoveterinary treatment of camels in Oman. in: Proc. 3rd Conf. Intl. Soc. Camelid Res. Dev., January 29, 2012. Sultan Qaboos University, Oman.

McCabe, J. T. 1987. Drought and recovery: Livestock dynamics among the NgisonyokaTurkana of Kenya. Human Ecology 15 (4): 371-389.

McCabe, J. T. 1990. Turkana pastoralism: A case against the tragedy of the commons. Human Ecology 18 (1): 81-103.

McCabe, J. T. 1995. Turkana. In D. Levinson(ed.) Encyclopedia of World Cultures. G. K. Hall-Macmillan Press and the Human Relation Area. New Haven, Connecticut 9: 370-373.

Nalder, L. F. 1937. A tribal survey of Mongalla Province. International Institute of African Languages and Cultures, Oxford University Press, 232

Ohta, I. 1984. Symptoms are classified into diagnostic categories; Turkana's view of livestock diseases. African Study Monographs 3: 71-93.

Ohta, I. 1987. Livestock individual identification among the Turkana: The animal classification and naming in the pastoral livestock management. African Study Monographs 8 (1): 1-69.

Opiyo, F., O. Wasonga, M. Nyangito, J. Schilling, and R. Munang. 2015. Drought adaptation and coping strategies among the Turkana pastoralists of northern Kenya. International Journal of Disaster Risk Science 6: 295-309.

Quibell, J. E. 1896. The Ramesseum with translations and comments by W. Spiegelberg and, The Tomb of Ptah-Hetep, copied by R.F.E. Paget and A. A. Pirie, with comments by F. LI. Griffith. Egyptian Research Account, London, 125

Robbins, M. E., and L. H. Robbins. 1971. A note on Turkana dancing. Ethnomusicology 15 (2): 231-235
Russell, T., and P. Kiura. 2011. A re-consideration of the rock engravings at the burial site of Namoratung'a South, Northern Kenya and their relationship to modern Turkana livestock brands. South African Archaeological Bulletin 66 (194): 121-128.

Rutten, M. M. E. M. 1989. The struggle for land and livestock among the Turkana, (ex) nomadic pastoralists of North-West Kenya. In The struggle for land worldwide, ed. G. Peperkamp and C.H.W. Remie, 48-71. NICCOS Nijmegen: Verlag Breitenbach Publishers, Saarbrucken-Fort Lauderdale.

Schwabe, C. W. 1984. A unique surgical operation on the horns of African bulls in ancient and modern times. Agricultural History 58 (2): 138-156.

Searight, S. 2004. The prehistoric rock art of Morocco. A study of its extension environment and meaning, BAR international series 1310, 333. Oxford: Archeopress.

Searight, S. 2013. Morocco's rock art: Age and meaning. Art 2: 35-43.

Seligman, C. G. 1932 Egyptian Influence in Negro Africa. In S.R.K. Glanville (ed.), Studies Presented to F. LI. Griffith, London Egypt Exploration Society, 457-462.

Seligman, C. G., and B. Z. Seligman. 1950. Pagan tribes of the Nilotic Sudan. New York: The Humanities Press.

Soper, R. C. 1982. Archaeo-astronomical Cushites: Some comments. Azania 17: $145-162$.

Thomas, E. M. 1966. Warrior herdsmen London: Secker \& Warburg.

Tornay, S. 1981. The Nyangatom: An outline of their ecology and social organization. In Bender, M. Lionel. Peoples and cultures of the Ethio-Sudan borderlands. East Lansing: African studies center, Michigan State University. 137-178.

Turkana County Government. 2013. County Integrated Development Plan (CIDP) 2013-2017. Lodwar: Turkana County Government

Turton, D. 1980. There's no such beast: Cattle and colour naming among the Mursi. Man 15 (2): 320-338.

Vandier, J. 1969. Manuel d'Archeologie Egyptienne. Tome V: 10-11.

Wienpahl, J. 1984. Livestock production and social organization among the Turkana (pastoralism, nomads; Kenya, East Africa). University of Arizona: Unpublished PhD dissertation

Wilkinson, C. 1979. Egyptian wall paintings: The Metropolitan Museum's collection of facsimiles. The Metropolitan Museum of Art Bulletin 36 (4): 2-56.

\section{Submit your manuscript to a SpringerOpen ${ }^{\circ}$ journal and benefit from:}

- Convenient online submission

- Rigorous peer review

- Open access: articles freely available online

- High visibility within the field

Retaining the copyright to your article

Submit your next manuscript at $>$ springeropen.com 